\title{
Work Index
}

Acta Lanfranci 77

Adalriks och Giöthildas Äfwentyr 165

Alexanders saga 118

Alexandreis 118

Amadigi (Händel) 159

Amadigi de Gaula 160

Amadis (Lully) 159

Amadis aus Griechenland 159

Amadís de Gaula 14, 157-171

Amadis de Grèce 159

Amadís, see Amadís de Gaula

Annales Danici 80

Astree Siunge-Choer 166

Astrée 166

Breviarium Arhusiense 75

Breviarium Lundense 75

Breviarium Nidrosiense 75

Canterbury Tales 120

Chronicon Lethrense 80

Chronicon Roskildense 80

Chronicon 95-98

Clári saga 118-121

Cur Deus homo 72

De sanctis et eorum pigneribus 94

De ueritate 72

Den beklædte sandhed 157, 165-168

Den Vægelsindede 166

Der Neue Amadis 160

Disciplina clericalis 114

Doctor Faustus 165

Don Quijote 160

Edda (poetic) 179

Edda (prosaic) 179

Filocolo 120

Filostrato 120

First Grammatical Treatise 175

Flores and Blancheflor 165

Gemma animae 33

Genealogia regum Daniae 81-82

Gesta Hammaburgensis ecclesiae pontificum 46
Gesta Danorum 71, 74, 83-87

Gesta et passio 77-80

Gesta Swenomagni regis et filiorum eius et passio gloriosissimi Canuti regis et martyris, see Gesta et passio

Gospel of John 27, 34

Griseldis 165

Heimskringla $175-176$

Hermanns saga ok Jarlmanns 118

Hexaemeron 85

Historia compendiosa, see Historia regum

Daniae compendiosa

História de l'esforçat cavaller

Partinobles 115-116

Historia lerosolimitana 72

Historia regum Britanniae 114

Historia regum Daniae compendiosa 81-83

Historiarum Florentini populi libri XII 88

Hortulus muliebris quadripartitus 160

Íslendingabók 14-15, 173-213

Jóns páttr biskups Halldórssonar 121

Karlamagnús saga 116

Landnámabók 176-177, 192-194, 198, 207, 211

Lárentíus saga 96-97

Las sergas de Esplendian, hijo de Amadís de Gaula 158

Legendarium Flandrense 79

Leges Scaniae 85

Levnet og Meeninger 167

Lex castrensis sive curiae 81-84

Lex castrensis 72

Libellus Islandorum 185-186, 193, 201, 204

Life of Canute Lavard 79-80

Los quatro libros del virtuoso cavallero Amadís de Gaula 158

Mabinogion 106

Magelone 165

Magnus Erikssons landslag 127

Mágus saga jarls 118

Margrétar saga 33 
Maríu saga 93, 95, 97-99, 116-117

Melusine 165

Monodies 94

Monologion 72

Nibelungenlied 119

Nikulás saga erkibyskups 73, 95

Octavian 165

Ólafs saga Tryggvasonar en mesta 177

Omelia dicenda die natalis sancti Wilbrordi 76

Oriana 159

Owain, neu larlles y Ffynnon 106

Partalopa saga 113-116, 118-119

Partonopeu de Blois 112-115

Passio sancti Kanuti regis et martiris 75-76

Peder Paars 166

Remigius saga 98
Res memorandae 121

Reynicke Vosz (Reynard the Fox) 165

Schedæ Ara Prests Fróda 173-213

Sigrdrífumál 32

Speculum Historiale 95

Stratonice 166

The Miracles of St Mary of Laon 94

Tristrams saga ok Ísöndar 118

Ulenspiegel 165

Västgötalagen 46

Weiblicher Lustgarten 160

Wolfdietrich 108, 110

Yvain ou Le Chevalier au lion 106, 110, 112 